\title{
SOME PHYSICAL AND CHEMICAL PROPERTIES OF TRADITIONAL HONEYS IN NEW DESERT REGIONS IN EGYPT
}

Fathy, H.M. ${ }^{1}$;E.I. Haggag ${ }^{2}$;M.I. sanad ${ }^{3}$ and M.R.M. Abd EL-Dayem ${ }^{2}$

1 Dept. Plant Protection, Fac. , Agric., Mansoura University, Egypt.

2 Beekeeping Research Department, Plant Protection Res Institute (PPRI), Agric. Res. Center, Giza, Egypt.

3 Dept. Agricultural Chemistry, Fac., Agric., Mansoura University, Egypt.

\begin{abstract}
Ten citrus and clover honeys samples as traditional honeys were collected from new desert regions in Egypt. Eight parameters were measured in clouding moisture, total soluble solid (T.S.S.), PH, Electric conductivity (EC), Free acidity, Lactone, Total acidity and hydroxy methyl furfural (HMF)

The results indicated that moisture was parallel and the average values in citrus and clover honeys were 20.33 and $19.25 \%$, respectively. The average values of EC, T.S.S., pH, Free acidity, lacton, total acidity and HMF in citrus and clover honey samples were 80 and $77.5,79.67$ and 80.75, 3.92and 3.83, 16.64 and 14.44, 8.85 and $9.7,25.85$ and $24.14,1.96$ and 1.32 , respectively.
\end{abstract}

\section{INTRODUCTION}

Honey standardization is an important object to study. Every country in all over the world has its special honey standard, depending on the different environmental factors existing in each country. Surveys of floral honey composition have established that the three major components are fructose, glucose, and water (Doner, 1977). Honey is the sweet substance produced by honey bee from the flowers or from secretions of living parts of plants, which honey bee collected, transform and combine with specific substances of their own, store and leave in honey comb to ripen and mature. (Codex Alimentarius 1998). Chemically, honey is quite complex. it comprised primarily sugars; however, it contains many other potentially biologically active components, such as antioxidants, which display antimutagenic activity (Wang et al., 2002). Recently, standardization of the honey depends on major nine tests have to be determined. They were reducing sugar content, sucrose content, fructose; glucose ratio, moisture content, water insoluble solids content, ash, acidity, diastase activity and hydroxy methyl furfural (H.M.F.) content. These tests need abig effort to study all honey types in the country regions.

The aim of this study were determination of physical and chemical properties of traditional honeys (citrus and clover) in new desert regions in Egypt. This work was carried out during they year 2010 and 2011 in Bee Research Department Plant protection Research Institute. 


\section{MATERIALS AND METHODS}

Ten traditional honeys sample (citrus and clover) were collected from new desert regions (North Sinai and Ismailia and New Valley and Al Menofia and Al Dakahlia) as in table 1

Table 1: Honey types and their different locations

\begin{tabular}{|c|c|c|c|}
\hline Sample & Honey types & Regions & Locations \\
\hline 1 & \multirow{6}{*}{ Citrus (Citrus spp.) } & North Sinai & Shiekh Zowied \\
\hline 2 & & North Sinai & Rafah \\
\hline 3 & & Ismailia & Ismailia \\
\hline 4 & & Ismailia & Fayed \\
\hline 5 & & Ismailia & Qantara East \\
\hline 6 & & Al Menofia & Ashmoun \\
\hline 7 & \multirow{4}{*}{$\begin{array}{l}\text { lover } \\
\text { alexandrinum) }\end{array}$} & New Valley & Al Dakhlah \\
\hline 8 & & (Trifolium|smailia & Ismailia \\
\hline 9 & & Al Menofia & Ashmoun \\
\hline 10 & & Al Dakahlia & Qlabasho \\
\hline
\end{tabular}

The physical properties, the moisture (\%) was measured according to (A.O.A.C., 1995), the total soluble solids (T.S.S.) was measured according to (A.O.A.C., 1980), the include electrical conductivity (EC) was measured according to (vorwohl, 1964).

In relation to chemical properties, $\mathrm{pH}$, free acidity, lacton and total acidity based on the method of (white et al., 1962). The hydroxy methyl furfural (HMF) was measured according to (AOAC 980.23. 1980).

\section{RESULTS AND DISCUSSION}

\section{Physical and chemical properties of Citrus honeys:-}

Data in table (2) show that citrus honey moisture ranged between 19 $21.5(\%)$ with mean value of $20.33(\%)$. Concerning the electrical conductivity (EC) the citrus honey ranged between $60-110(\mathrm{ppm})$ with a mean value of $80(\mathrm{ppm})$, where as total soluble solids (T.S.S.) ranged between 78.5- 81(\%) with a mean value of $79.67 \%$. Also in table (2), the chemical properties of Citrus honey sample indicated that, the $\mathrm{pH}$ value ranged between $3.74-4.41$ with a mean value of 3.92. The free acidity ranged between 10.17 and 22.67 with a mean value of 16.64 . 
Table (2):- Physical and chemical properties of Citrus honey collected from new desert regions in Egypt.

\begin{tabular}{|c|c|c|c|c|c|c|c|c|c|c|}
\hline 号 & 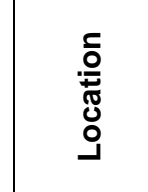 & $\begin{array}{l}\frac{0}{0} \\
\text { लू } \\
\text { लొ }\end{array}$ & 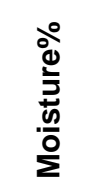 & 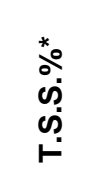 & 总 & I & 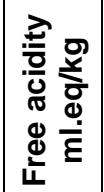 & 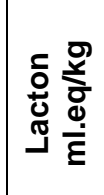 & 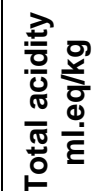 & 佡 \\
\hline \multirow{2}{*}{$\begin{array}{l}\text { North } \\
\text { Sinai }\end{array}$} & $\begin{array}{l}\text { Shiekh } \\
\text { Zowied }\end{array}$ & 1 & 21.5 & 78.5 & 70 & 3.76 & 22.67 & 10.33 & 33 & 1.048 \\
\hline & Rafah & 2 & 21.5 & 78.5 & 60 & 3.81 & 17.67 & 3.25 & 20.92 & 3.039 \\
\hline \multirow{3}{*}{ Ismailia } & Ismailia & 3 & 19 & 81 & 110 & 4.41 & 10.17 & 16.67 & 26.83 & 2.894 \\
\hline & Fayed & 4 & 19.5 & 80.5 & 70 & 3.74 & 17.33 & 6 & 23.33 & 0.349 \\
\hline & $\begin{array}{l}\text { Qantara } \\
\text { East }\end{array}$ & 5 & 20.5 & 79.5 & 110 & 3.78 & 19.5 & 9 & 28.5 & 1.597 \\
\hline \begin{tabular}{|l|} 
Al \\
Menofia
\end{tabular} & Ashmoun & 6 & 20 & 80 & 60 & 4 & 12.5 & 7.834 & 20.33 & 2.815 \\
\hline \multicolumn{3}{|c|}{ Variation limits } & $\begin{array}{l}19- \\
21.5\end{array}$ & $\begin{array}{c}78.5- \\
81\end{array}$ & $\begin{array}{l}60- \\
110\end{array}$ & $\begin{array}{c}3.74- \\
4.41\end{array}$ & \begin{tabular}{|c|}
10.17 \\
22.67
\end{tabular} & $\begin{array}{l}3.25- \\
16.67\end{array}$ & $\begin{array}{c}20.33 \\
33\end{array}$ & $\begin{array}{l}0.349 \\
3.039\end{array}$ \\
\hline \multicolumn{3}{|c|}{\begin{tabular}{|l|} 
Average values \\
\end{tabular}} & 20.33 & 79.67 & 80 & 3.92 & 16.64 & \begin{tabular}{|l|}
8.85 \\
\end{tabular} & 25.85 & 1.96 \\
\hline $\begin{array}{l}\text { T.S.S.\%** } \\
\text { EC } C^{\star} \text { ppm }\end{array}$ & tot & & & & & & & & & \\
\hline
\end{tabular}

The lacton content ranged between 3.25 and 16.67 with a mean value of 8.85 . While the total acidity value (free acidity + lacton content) ranged between 20.33 and 33 with a mean value of 25.85 . The content of citrus honey sample hydroxy methyl furfural (HMF) showed low values as the values ranged between 0.349 and 3.039 with a mean value of 1.96 .

Physical and chemical properties of clover honeys:-

Data in table (3) show that clover honey moisture ranged between 18.75 and 20.25 (\%) with mean value of $19.25(\%)$. Concerning the electrical conductivity $(\mathrm{EC})$ the citrus honey ranged between $60-90(\mathrm{ppm})$, where as total soluble solids (T.S.S.) ranged between 79.75 and $81.25(\%)$ with a mean value of $80.75(\%)$. Data presented in table (3), indicated the chemical properties of Clover honey sample. The $\mathrm{pH}$ value ranged between 3.7and 3.98 with a mean value of 3.83 . The free acidity ranged between 11.5 and 20.25 with a mean value of 14.44 . 
Fathy, H. M. et al.

Table (3):- Physical and chemical properties of Clover honey collected from new desert regions in Egypt.

\begin{tabular}{|c|c|c|c|c|c|c|c|c|c|c|}
\hline 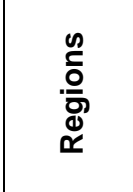 & 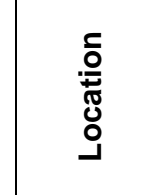 & $\begin{array}{l}\frac{0}{2} \\
\frac{0}{0} \\
\frac{0}{E} \\
\text { ले }\end{array}$ & 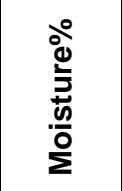 & $\begin{array}{l}\stackrel{*}{\circ} \\
\stackrel{\leftrightarrow}{\circ} \\
\stackrel{\leftrightarrow}{\leftarrow}\end{array}$ & 엄 & I & 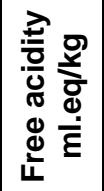 & 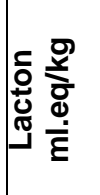 & 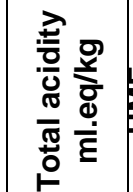 & 岌 \\
\hline \begin{tabular}{|l} 
New \\
Valley \\
\end{tabular} & \begin{tabular}{|l|} 
Al \\
Dakhlah
\end{tabular} & 7 & 19 & 81 & 60 & 3.85 & 12.33 & 2 & 14.33 & 2.121 \\
\hline Ismailia & Ismailia & 8 & 18.75 & 81.25 & 80 & 3.98 & 13.67 & 11 & 24.67 & 1.425 \\
\hline $\begin{array}{l}\text { Al } \\
\text { Menofia }\end{array}$ & Ashmoun & 9 & 20.25 & 79.75 & 90 & 3.79 & 20.25 & 8.625 & 28.88 & 1.362 \\
\hline \begin{tabular}{|l|} 
Al \\
Dakahlia \\
\end{tabular} & Qlabasho & 10 & 19 & 81 & 80 & 3.7 & 11.5 & 17.17 & 28.67 & 0.369 \\
\hline Variation & limits & & $\begin{array}{c}18.75- \\
20.25 \\
\end{array}$ & $\begin{array}{l}79.75- \\
81.25 \\
\end{array}$ & $\begin{array}{c}60- \\
90 \\
\end{array}$ & $\begin{array}{l}3.7- \\
3.98 \\
\end{array}$ & \begin{tabular}{|l|}
$11.5-$ \\
20.25 \\
\end{tabular} & $\begin{array}{c}2- \\
17.17 \\
\end{array}$ & \begin{tabular}{|c|}
$14.33-$ \\
28.88 \\
\end{tabular} & $\begin{array}{l}0.369 \\
-2.12 \\
\end{array}$ \\
\hline verage & values & & 19.25 & 80.75 & 77.5 & 3.83 & 14.44 & \begin{tabular}{|l|}
9.7 \\
\end{tabular} & 24.14 & 1.32 \\
\hline
\end{tabular}

The lacton content ranged between 2 and 17.17 with a mean value of 9.7. While the total acidity value (free acidity + lacton content) ranged between 14.33 and 28.88 with a mean value of 24.14. The content of clover honey sample with hydroxy methyl furfural (HMF) showed low values. The values ranged between 0.369 and 2.12 with a mean value of 1.32 .

The data in table (4) showed clear differences in free acidity values among the tested honey samples.

The free acidity in citrus honey followed by clover honey samples the highest mean value among the tested honey sample (mean 16.64 and 14.44 milliq/kg), respectively. These results were not accepted by Egyptian standard (2005). The high value of lacton content were recorded in clover honey while the low values of lacton content were recorded in citrus. The values of total acidity in all tested honey samples were higher in the Egyptian standard (2005).

Citrus samples showed the highest HMF content (mean $1.96 \mathrm{mg} / \mathrm{kg}$ )

Than clover honey (mean $1.32 \mathrm{mg} / \mathrm{kg}$ ). This may by due to the effect of climatic conditions in different locations especially the high temperature in Rafah region. 
Table (4):- Means of physical and chemical properties for all honey sample (Citrus and Clover).

\begin{tabular}{|c|c|c|c|c|c|c|c|c|}
\hline \multirow[b]{2}{*}{$\begin{array}{c}\text { Honey } \\
\text { type }\end{array}$} & \multicolumn{8}{|c|}{ physical and chemical properties } \\
\hline & 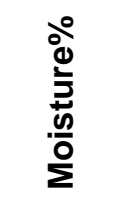 & $\begin{array}{l}\stackrel{*}{\circ} \\
\text { cं } \\
\text { ஸे } \\
\stackrel{-}{-}\end{array}$ & 总 & I & 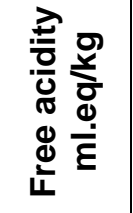 & 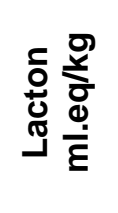 & 종 & 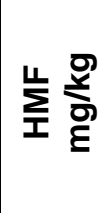 \\
\hline $\begin{array}{l}\text { Citrus } \\
\text { honey }\end{array}$ & 20.33 & 79.67 & 80 & 3.92 & 16.64 & 8.85 & 25.85 & 1.96 \\
\hline $\begin{array}{l}\text { Clover } \\
\text { honey }\end{array}$ & 19.25 & 80.75 & 77.5 & 3.83 & 14.44 & 9.7 & 24.14 & 1.32 \\
\hline Range & $\begin{array}{r}19.25- \\
20.33 \\
\end{array}$ & $\begin{array}{c}79.67- \\
80.75 \\
\end{array}$ & 80 & $\begin{array}{c}3.83- \\
3.92 \\
\end{array}$ & $\begin{array}{c}14.44- \\
16.64 \\
\end{array}$ & $\begin{array}{c}8.85- \\
9.7 \\
\end{array}$ & $\begin{array}{c}24.14- \\
25.85 \\
\end{array}$ & $\begin{array}{c}1.32- \\
1.96 \\
\end{array}$ \\
\hline Mean & 19.79 & 80.21 & 78.75 & 3.875 & 15.54 & 9.275 & 24.995 & 1.64 \\
\hline 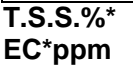 & & - & nolide & & & & & \\
\hline
\end{tabular}

Generally, the physical properties of the most honey samples were not in the range values as mentioned buy the specification of the Egyptian honey standard 2005. This may be due to the abnormal practices occurred by the beekeepers towards their honey bee colonies during the honey flow, or gathering the honey from these colonies before complete ripening. Many authors discussed the physical properties.

Water content in Egyptian honeys was found by (Ibralim et al., 1977) to be $18-19.5 \%$, by (vorwohl et al., 1989) to be $16.3-22.3 \%$ with mean $18 \%$ and by (Gomaa, 2002) to be 15.4 to $22 \%$.

\section{REFFERENCES}

A. O. A. C. (1980) Official methods of analysis. Washington, DC: Ass off. Ana. chem.

A. O. A. C. (1995) Official methods of analysis. (16thed).Washington, DC: USA: Ass. Off. Ana. Chem..

A. O. A. C. (1998) The 16th edition of the Official Methods of Analysis, 4th Revision, current through March, Washington, DC: USA: Ass. Off. Ana. Chem..

Codex Alimentations Commission (1998) Recommended European Regional standard for honey (CAC/RS 12-1969).

Doner, L. W. (1977) The sugars of honey-A review, J. Sci. Food Agric., 28, 443-456.

Gomaa, W. M. K. (2002) studies on honey quality with special reference to the Egyptian honey standard, M.Sc. thesis, Fac. Agric., Alex. Uni. Egypt, 156pp. 
Fathy, H. M. et al.

Ibrahim, S. H.; N. Z. Soliman and H. Wissa.(1977) studies on the properties of the major Egyptian honey types and on honey ripening Agric. Res. Rev., 55:125 -129.

Vorwhol, G. (1964a) Dia Messung der elektrischen heitfahigkeit des honig und die vermendung der Messwerte zur Sortendignose und zum Nachweis von vervals chungenmit zuckerfutterung shonig, Bienenforschung, 7,37-47.

Vorwhol, G.; M. S. Salem and M. E. Nour (1989) Chemical and Physical properties of Egyptian honeys. Proc. 4 Int. Conf. Apic. Trop. Climates, Cairo,:240 - 244

Wang, X. H.; Andrae, L. and Engeseth, N. J. (2002) Antimutagenic effect of various honeys and sugars against, J. Agric. Fd. Chem., 50, 69236928.

White, J. W.; Riethof, M. L.; Sobers, M. H. and Kushnir, I. (1962) Composition of American honeys, U.S., Dept. Agric., Tech. Bull., 1-124.

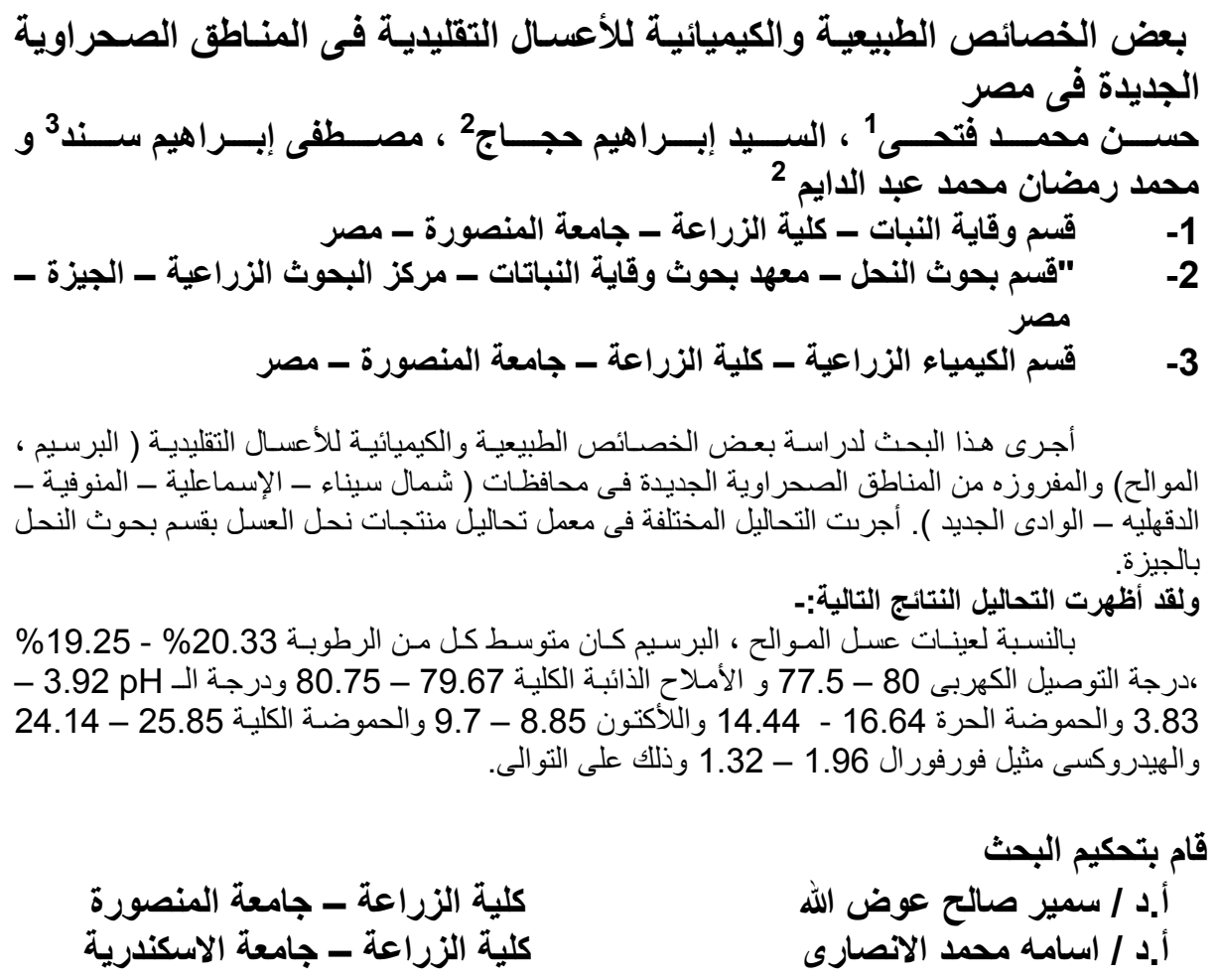

